Original article

\title{
DEVELOPMENT THROUGH INTERVENTION? REVISITING CRITICISM OF HUNGARIAN DEMOCRACY ${ }^{1}$
}

\author{
Marton Gellen \\ University of Public Service, Faculty of Public Governance \\ and International Studies. Budapest, Hungary. \\ Address: 2 Ludovika tér., 1083 Budapest, Hungary. \\ E-mail: gellen.marton@uni-nke.hu
}

\begin{abstract}
Hungarian public administration culture has traditionally been considered as overtly legalistic and proceduralist, which appears to be in contrast with claims of weakening the rule of law or facing sanctions under Article 7 of the Treaty of the European Union. This article offers an overview on the criticisms put forth by academic writers and EU institutions regarding the Hungarian development path and puts them into the wider context of democratization through transaction (transitology, democracy export) theory.

The article compares findings of contemporary interventionist authors with the propositions of such iconic writers as Dankwart Rustow (1970) and Samuel P. Huntington (1984) and attempts to connect the dots between these realms of thought. These authors all share the view that democracy shall be exported the more and quicker the better. Transitology, though, has had its critics, while contemporary interventionist theory appears to be rather monolithic without considerable criticism. The article uses the approach of Payne (2006), and of other authors, to question various statements of contemporary interventionists.

Not least, recent developments in Afghanistan provide historical evidence that the ambitions of transactional democratisation are predetermined to fall short on nondemocratic institutions imposing democracy using non-democratic measures on recipients of various sorts.
\end{abstract}

Keywords: public administration culture, democratisation, interventionist theory, transitology, transactional democratisation.

1 Proposal for EGPA Conference 2021. 
For citation: Gellen, M. (2021) 'Development through intervention? Revisiting criticism on Hungarian democracy', Public Administration Issues, 6 (Special Issue II, electronic edition), pp. 84-102 (in English). DOI: 10.17323/1999-5431-2021-0-6-84-102.

\section{The realm of transitology - an almost forgotten approach: transition by transaction}

Article 7 of the Treaty of the European Union and its potential or actual application against Hungary and Poland created a new sub-field of scientific research and debate in academic law, political science and public policy. In the following, I put forth a potential conceptualization regarding the Hungarian and (partly on the) Polish examples of paths to democratization.

In this section, I put forth the most important findings of transitology in order to highlight how contemporary interventionist theory developed. 'Interventionist', 'transitology', and 'democratise by transaction' are expressions that refer to the same phenomenon: certain countries' ambitions to spread their interpretation of democracy to other countries. The means have evolved throughout history but the ends have remained basically unchanged.

"Democratization from authoritarian rule has been one of the most intensely studied topics of the 1980s" - said Donald Share at the 1985 Annual Meeting of the American Political Science Association in New Orleans (Share, 1987).

Dankwart A. Rustow (1970), Samuel P. Huntington (1984), James L. Payne (2006) and Jeffrey Sachs (the latter being in the field of economics and known to be the promoter of mass-privatisation; not discussed here in detail) are probably the most renowned authors in 'transitology' applied to the democratisation of Latin America and Central and Eastern Europe. The common view they held was that democracy is not necessarily a result of socio-economic forces that organically grow in the womb of history. On the contrary, it is possible, furthermore, desirable to export democracy if one has the proper means to do so.

Seymour Martin Lipset (1959) called the attention to widespread literacy and urbanisation as necessary preconditions of democracy. Others focused on economic circumstances such as per capita income (Cutright, 1963). A good public sentiment for participation in elections and in civil groups is considered beneficial for the development of democracies (Lerner, 1958; Almond and Verba, 1963).

As Dankwart Rustow put forth in his seminal article of 1970, there is a longobserved tendency in human nature that underpins the tendency for democracy (Rustow, 1970), this remark of his having a certain Hegelian flavour. Rustow differentiates authors who put emphasis on consensus or at least having certain elements of consensus among the political actors, mainly consensus in the rules of the game (Barker, 1942) whose line of theory can be led back to Hobbes and Montesquieu in terms of the principle of society founded on consensus. Rustow (1970) identifies a large chunk of academic writing using circular arguments on how existing 
democracies might be able to be preserved against non-democratic tendencies, at that time personified by the Soviet Union.

What puzzled 'transitologists' in the 1970s was that the Anglo-Saxon culture yielded democracies that proved to be stable over time whereas Germany and France, not to mention Mediterranean and non-European countries, had merged from democracies to non-democratic regimes (back and forth) at various points in history. Rustow's main argument - that made him the central author of transitology - was that democracy's genetic and functional prerequisites ought to be differentiated, reminding us that variables of correlation and causation have to be thoroughly separated. He does not accept the tacit assumption that cultural and socio-economic realities are deeper than political-institutional superstructures. "...to promote democracy you must first foster democrats - perhaps by preachment, propaganda, education, or perhaps as an automatic by-product of growing prosperity. Instead, we should allow for the possibility that circumstances may force, trick, lure, or cajole non democrats into democratic behavior and that their beliefs may adjust in due course by some process of rationalization or adaptation" (Rustow, 1970, pp. 344-345). Seeking causality - according to Rustow - requires precise adaptation to the given circumstances of the country in question, thus, there is no universal pathway to democracy, indeed, there is no universal timeframe for democratisation: certain cases may last several generations, such as Britain, but others - given the proper examples and external actors - can be speeded up. Rustow proposes the following scheme for democratic transitions:

1. Certain ingredients are indispensable to the genesis of democracy. For one thing, there must be a sense of national unity and stable borders.

2. Entrenched and serious power conflict.

3. Conscious adoption of democratic rules.

4. Habituation: both politicians and electorate must be habituated to these rules.

5. Additionally: the phases shall be performed as a concentrated sequence of events, in a relatively short period of time.

Share classifies the democratisation proposed by Rustow as "transition through transaction" in contrast to incremental democratisation and democratisation by "protracted revolutionary struggle" and rupture (inclusively revolution, coup, collapse, extrication) (Share, 1987). Share mentions the historical example of Carlos Arias Navarro's attempt to implement certain liberal reforms without altering the authoritarian basis of the Franco regime of Spain. This serves as an argument that liberalisation can happen without democratisation and institutional democratisation may follow afterwards. In hindsight, this is the same pattern of events that actually took place in Hungary: new economic reforms from 1968 allowed small private ownership in agriculture, later the Presidential Council (the equivalent of the Government) of the People's Republic of Hungary issued the Decree of Law-force No. 15 of 1981 that opened the possibility of private ownership in small industry. In 1988 - still under massive dictatorship the Act on Company Law was issued (No. VI. of 1988) that hallmarked the wave of "spontaneous privatisation" signifying the conversion of political clout and connections acquired in the People's Republic to be transferred as economic power and ownership in the young democracy. 
The influence of transitology on contemporary thought: The EU becoming the vehicle of democratisation

Authors in the 1990s agreed that the changes were 'exceptionally speedy' (Kornai, 1996). Speediness, however, can be viewed as an optical delusion given that changes of liberalisation started in the 1960s. In 1967 ( $7^{\text {th }}$ of March), the Political Commission of the Hungarian Socialist Workers' Party gave its consent to engage in informal consultations with international financial institutions, which materialised into becoming a member of the IMF in 1982. Another source of delusion of analyses regarding the Hungarian development path may be the question as to whether these speedy changes were complete or not. It would have been possible to take Rustow's analysis seriously that there should be a serious power conflict between the supporters of dictatorship and democracy. In Hungary, such conflict was intangible except for the taxi drivers' blockade in 1990 which happened to use public action against the democratically elected government of the day. The open questions on whether democratisation was complete or not puts the lack of lustration or the alleged economic power grab or the retirement rules of the judiciary into an entirely different context. If one uses the incompleteness of democratisation as a premise, it appears logical to assume that certain steps that may appear as a backsliding of democracy are indeed against the former beneficiaries of the dictatorship who had entrenched themselves in the institutions of the new era.

In her recent published research, Zsuzsanna Borvendég, a historian, stated that the darkest years of the cold war created enormous business opportunities for east-west trade which were exploited by both sides as early as 1945, right after WWII (!) and came to flourish during the 1970s and 1980s through entitled export-import companies, some of which still exist (Borvendég, 2020). These remarks underpin Rustow's theory of externally driven democratisation or Share's transactional democratisation theory from the historian's perspective.

Rustow's proposition on democracy export through transactional democratisation received recognition by no less influential an author than Samuel P. Huntington (1984). According to Huntington's view put forth in 1984, the US, and especially the Reagan Administration, had a historical mission of spreading democracy in the world which was in line with American interests. Admitting that Rustow's approach is relevant, Huntington emphasizes that democracy is more than transaction and more than exporting democratic institutions: it does have substantial preconditions such as economic wealth and equality, social structure (especially civic participation and autonomous intermediate groups, pluralism), market economy and external factors (military conquest or colonisation by a democratic power for example). Regarding Eastern Europe, Huntington proposes the following policies:

- assisting economic development and promoting equitable income and wealth distribution;

- fostering market economies and the "development of vigorous bourgeois classes" (p. 218.); 
- refurbishing American economic, military and political power in order to be able to promote democracy by greater influence;

- develop, encourage, help and train elites of countries entering the transition.

Democratisation through transaction has been a massive line of thought regarding Central and Eastern Europe ever since. There are two major differences though compared to the period analysed by Rustow and Huntington: the number of international stakeholders with the ambition of democratising countries increased in recent decades while their influence deepened. "In virtually any area of policy in Central and East European countries, one can find transnational actors assisting state reforms and societal organizations active in that area. International organizations and expert networks have provided critical aid to economic reform teams..." (Orenstein, et al., 2008, p. 2). The comprehensive work of Iwona Sobis and Michiel de Vries (2009) on the details of how such expert networks and international stakeholders actually worked during the 1990s and early 2000s shall be mentioned in this context. Their judgement is far from idealistic regarding the process of democratisation in the region. They argue that international technical assistance (worth approx. USD 40 Billion) served the interests of the assistants rather than those of the countries being assisted.

Vachudova (2008) depicts the role of the European Union as the "causal Behemoth" of influence. She accepts the Rustowian approach of transactional democratisation in the sense that democratisation relies more on concrete international and domestic actors than subtle socio-economic conditions. Vachudova (2008) commences her analysis on the role of the EU in democratising Central and Eastern Europe by hinting that these countries have been traditionally close to or had even been internal colonies of either Moscow or Berlin and becoming members of the EU club represented a "huge reversal" (p. 20.) for them.

\section{Criticism and alternatives to the Rustowian approach}

The example of Iraq's democratisation was used by James L. Payne (2006) to demonstrate his criticism of 'democratisation by transaction' theory and practice. He uses the failure of democratisation in Iraq to establish his argument contrary to Harvard Professor of Human Rights (and president of Central European University in Budapest) Michael Ignatieff (2005) who had urged an "American crusade" to spread democracy. The blueprint was taken by Ignatieff from Diamond, Linz and Lipset's (1989) work on the example of the post-WWII era claiming that democracy was successfully "imposed" on Germany, Italy and Japan. In agreement with Huntington (1984) and Share (1987), Payne (2006) emphasizes the necessity of wealth accumulation as being in a causal relationship with democracy. However, Payne refers to the American privation policy towards Germany which aimed at punishing the country in economic terms, furthermore, foreign aid programs are definitely not connected by causality to the establishment of democracies. Education for democracy (such as nazi education previously) proved futile in terms of influencing the political behaviour of the German population. Even further, Payne concludes that Americans had no considerable role in creating the German constitution. 
Payne's approach is diametrical to Ignatieff's. He summarises his position as follows: "The factor I would propose is a variable that has been strangely neglected in the study of democracy: moderation of the amount of leadership political violence. Where political leaders are inclined to use violence against each other - violence in the form of political murders, gang attacks, and armed revolts - democracy cannot survive. It will tend to collapse into civil war or a repressive dictatorship." (Payne, 2006, p. 219) Payne sees the sources of democracy and democratisation as endogenous factors, out of which internal security and nonviolence are endemic. Ignatieff (2005) however, views democracy as a simple matter that can be imposed by sanctions or even by the use of military violence.

Democracies have better and worse periods (Fukuyama, 2012). According to Fukuyama's account, American democracy underwent a devastating phase whereas 'liberal populism' failed to live up to its promises, distorted trust and removed the general public's sentiment of a middle class and egalitarian society. As such, Fukuyama allows that democracy has its own internal mechanism that moves it towards development or degradation. As long as it keeps its internal stamina, it can correct itself sooner or later. Yoram Hazony (2018) also occupies a stance that describes democracy as an organic and context-bound phenomenon. According to his account, democracies by definition constitute national level democracies and reject supra-national polities such as empires.

Complexity theory applied to public policy also supports the latter idea. If the general course of collective action (democracy) is imposed or controlled by another system, the complex (adaptive) system of the day will struggle to turn back to its own development path. If this path of return to its own systemic normality is blocked, the system cannot be called a system any more (Morçöl, 2014).

Joseph Ratzinger also occupies the stance of the moral-organic-consensual nature of democracy (Ratzinger, 2007, p. 738). Even Jürgen Habermas and Joseph Ratzinger occupy the consensual-organic view of democracy and modern state in their famous discussion (2007) starting with the 'Böckenförde theorem' ('Can a secular state guarantee its own moral basis?') although with different viewpoints (Habermas and Ratzinger, 2007). An organic-sustainable vision of democracy is also supported by Shiva $(2005,2015)$, whereas duties and responsibilities are emphasized, such as rights.

The list of influential contemporary thinkers emphasizing various organic and/or context-bound views of democracy in contrast to transactional/imposed concepts of democracy could be extended at length. The cited authors' works demonstrate that the former is by no means inferior to the latter, however, EU institutions appear to occupy the position of bureaucratized-transactional democratisation.

\section{Country-specific critical theories}

\section{Democratic backsliding theory}

It is worth noting that in Hungary one can observe a steadiness of general consensus regarding the political cycles: power has always been handed over on time and election cycles have never been shortened or extended between 
1990 and the present. The adamant adherence to the democratic procedure is a characteristic that would fall into Rustow's (1970) category of habituation. Another important element of steady consensus is that of refraining from violence towards political opponents fulfilling the paramount criterion of Payne's (2006) analysis. Violence directed against the political opposition appeared only in October, 2006 when armed police battalions - using potentially lethal rubber bullets, telescopic batons, plastic cable ties, and makeshift detention centres and flawed judicial proceedings were applied against Fidesz supporters and MPs by the Socialist-Liberal government ${ }^{2}$.

According to Ágh (2013), in the early years of the second Orbán Government ${ }^{3}$ there were such immediate changes in the previously relatively steady development path that the new phenomena should be considered as backsliding in democracy. Attila Ágh, turning away from his previous thoughts of desirable development (Ágh, 1975a, 1975b, 1984) emphasized a change of style in politics, politicisation of the civil service and centralization of public administration as non-democratic tendencies: taking control of the media and changing election rules, the Parliament electing a politically loyal attorney general, and dismissal of civil servants have to be considered as political cleansing. The forms of tripartite consultations (employers, employees, government) were substituted with separate consultations and numerous professional chambers (Agricultural Chamber, Lawyers Chambers, Medical Doctors' Chamber, Chambers of Commerce and Industry, etc.) were entitled with public duties and rights which was considered corporatist and therefore per se antidemocratic by Ágh (2013). Ágh appears to accept Rustow's theory of transactional democratisation emphasizing that in theory the transitional period (exporting and implementing institutions) would result in consolidation (habituation) of the new institutional order. According to him, the cause of this abrupt change is that one party achieved a landslide victory at the 2010 elections acquiring a supermajority (political cause). This brought to the surface the asynchronous nature of the development of polity, economy and society, and sure enough, adaptive Europeanization was incomplete which in itself refutes mainstream theory that views democratisation as a constant evolutionary process. The main elements of structural distortions of the beneficial evolutionary development path were poverty due to loss of Eastern markets and unjust redistribution via giveaway privatisation completed with the loss of civic participation.

Ágh views 2006 police brutality and judicial oppression of democratic participation as a violent remobilization of a right-wing mob. At this point in time, history apparently refutes him ${ }^{4}$. Ágh is also mistaken in that extreme-right Jobbik would ever have been a twin party of Fidesz. In fact, it formed a unified

\footnotetext{
2 URL: https://www.aljazeera.com/news/2006/10/23/street-protests-intensify-in-budapest (accessed $22 \mathrm{Au}$ gust 2021)

3 Viktor Orbán was the first prime minister of Hungary between 1998-2002, and 2010-2014 was his second term.

${ }^{4}$ For more information: Civil Jogász Bizottság jelentése a 2006 szeptember-októberi emberi jogsértésekről. [Report of the Civic Lawyer Commission on the breaches of human rights September-October, 2006] Kairosz Publisher, 2007.
} 
opposition with socialists and liberals who were not bothered by its apparent anti-semitism.

Ágh (2013) - as Vachudova (2008) - views the EU as a powerful actor of democratisation despite its apparent democratic deficit.

\section{The abrupt change theory - interventionist approach}

Pech and Scheppele link Viktor Orbán's speech on illiberal state to Art. 7 of the Treaty of the European Union, which regulates the so-called 'nuclear option' (Pech and Scheppele, 2017b). The authors as such link research on political science to legal research and furthermore to legal argumentation.

Pech and Scheppele (2017b) agree with Kochenov (2008) that the establishment of a nuclear option had highlighted certain regret or leaning towards retrospective correction of the Copenhagen criteria or even the entire decade-long accession period. According to Pech and Scheppele (2017b), the EU Commission wasted too much time on futile discourses with Poland and Hungary, whereas the Commission should instead have launched pre-emptive 'nuclear' strikes on these countries in order "to prevent the occurrence of a consolidated autocracy in violation of EU values is to act fast as soon as the danger signals are clear." What the latter words on timing mean in substance, they fail to describe, except for their emphasizing a "recommendation for speed".

Unlike Ágh (2013), Pech and Scheppele (2017b) do not elaborate on explanatory research on the causes of democratically elected political leaders' turning into autocrats overnight (as suggested in stage 2 of Pech and Scheppele) or how come that given the public resistance, such new autocrats can win several elections or even lose elections in certain important constituencies (as happened at the municipal elections in 2018 in Hungary). In fact, the so-called new autocrats perform rather badly in suppressing opposition, perhaps even so much that they do not live up to their reputation of being autocrats at all. The authors rather promote the idea that the EU should intervene in order to restore democratic processes by initiating Art. 7 TEU. How exactly the Art. 7 procedures would be in a causal relationship with the change of a democratically elected government in the Rustowian sense remains unclear. As a bottom line, the authors opt for a new institutionalization of Europe as a two-tier polity.

Kelemen and Blauberger (2017) promote the idea that Orbán undermined the independence of the judiciary and, furthermore, engaged in illiberal democracy, therefore he should be sanctioned, but actually imposing Art. 7 sanctions on Hungary were unlikely because of the internal power composition of party politics of the European Parliament. Soyaltin-Colella (2020) also promotes the idea that Hungary and Poland should be sanctioned by the EU, indicating that a large chunk of academic work deals with inter-institutional power struggles between EU institutions regarding Art. 7. The European Parliament has never been meagre on harsh communication towards Hungary and Poland and has always been ready to defend the democratic and liberal democratic path of development. Unlike the EP, the Council of the EU demonstrated a marked reluctance to apply sanctions. Soyaltin-Colella (2020) provides a list of actions that support the backsliding theory: 
- Changing the powers of the Constitutional Court by the new Constitution.

- Lowering the judicial retirement age and stacking courts with loyalists.

- Accountability and legal oversight of numerous government institutions has been changed, notably the Central bank and the data protection ombudsman.

- $\quad$ Restricting the freedom of the press.

- $\quad$ Rigging the electoral system.

- Stifling independent civil society organisations.

Similarly, according to Attila Ágh's account, Soyaltin-Colella appears to be refuted by history that elections were "rigged" or there would be government oversight of the Central Bank.

\section{The practical applicability of Art. 7 TEU}

A large chunk of corresponding theory deals with the technical details of the actual application of Art. 7 TEU.

Kelemen and Blauberger (2016) emphasize that all member states, including Hungary and Poland, committed themselves to Art. 2 values, thus there is a certain level of consensus among all countries, even the ones about to be sanctioned. With this argument, the authors offer a reply on the fundamental question of whether sanctioning certain member states affects the consensual element - and implicitly the cohesion - of the Union.

Rech (2018) takes a critical view of Igniatieff's (2005) stance according to which strengthening liberal democracy by coercion was a valid application of actual democratisation. Rech suggests the logical remark that the EU may risk its liberal and democratic values by imposing monism of values on countries instead of pluralism of values (Rech, 2018, p. 335). In fact, Poland and Hungary were both disciplined by the EU when they intended to modify retail sector taxation in favour of small businesses. Such policy steps are sympathetic to the electorate and suppressing them undermines public support of the EU as a promoter of democracy and public good. Rech (2018) offers an overview of various concepts of democratisation within the EU:

- Agreement by all member states to be democratised (minimalist-positivist argument).

- Upholding constitutional values is necessary to maintain a supranational entity (existential argument).

- Upholding rule of law and democracy contribute to the stability, peace and prosperity of the EU (teleological argument).

These arguments are usually mixed and used interchangeably in EU documents but these do not necessarily support the legal homogeneity let alone a common political culture (Habermas, 1996) and, as such, there ought to be a right for dissent but this appears not to have such ample institutional leverage as homogenisation (Ropret, Aristovnik and Kovac, 2018).

Hellquist (2019) uses the metaphor of ostracism to describe the relationship of the EU and countries under Art. 7. Ostracism is a way to silence dissent in the form that uses the power of multitude against a minority. According to her analysis, sanctioning and being sanctioned create moral superiority for the actor of the sanctions and renders the other party morally inferior. Citing Jean-Claude Juncker 
and Federica Mogherini, Hellquist (2019) throws light on the fact that the leaders of the EU were thinking about sanctioning internal and external entities in order to maintain (their) "credibility", however, the practice of sanctioning internally and externally reveals grave discrepancies. Hellquist rightly captures that internal sanctioning does not create European unity of cooperation and thus causes the dilemma of mutual harm of the actor and receiver of sanctions. Furthermore, Hungary and Poland hold a trump card as being democratically elected unlike the Commission. On the other hand, Hellquist (2019) is obviously mistaken that the far right were part of the government coalition in Hungary (it has never been, and it is part of the united opposition with liberals and socialists - a repetitive error of international authors).

Closa (2019) also assumes that there was an actual rule of law crisis in Hungary and in Poland, citing interventionist Pech and Scheppele (2017a). After interviewing Commission officials, Closa found that (interventionist) scholarly criticism by Kelemen (2017), Pech and Scheppele (2017a, b) and Kochenov (2016) made Commission officials justify their actions as to why they had been limited to infringement procedures. One of the justifications was that the EP was not ready to act politically. Officials had to calculate the chances of getting a 4/5 majority in the Council where the voters had to consider the political costs of their vote (e.g. Slovakia would have to consider that it would get into a semi-isolated position between Hungary and Poland. The Baltic States, or Romania would feel cut off.). Hungary and Poland would also mutually defend one other. The author concludes that the EU lacks last instance coercion to overcome recalcitrant governments regardless of there being democratically elected.

Appel (2019) continues the legacies of democratisation by transaction urging a joint international effort combined with street demonstrations to overturn current policies and possibly the democratically elected governments as well.

Kazai (2021) joins the interventionist choir by scrutinizing legislative processes in Hungary by quality and quantity. He does not put his analysis into a wider perspective. Legislation has always had its flaws in Hungary such as annual budgets being regularly accepted overnight during the last days of the year in the 1990s, but viewing law itself as an adversary of rule of law is a contradiction of terms in a traditional Rechtsstaat country where hard law published in the Official Journal of the country has always been paramount to soft law or judicial practice.

Ovádek (2018) accepts the existential position emphasizing that the punishment of Poland and Hungary is necessary for the unity and cohesion of the EU as a community. Ovádek (2018) puts forth the difference of legality as the thin concept of rule of law from the thick concept that embraces fundamental rights and democracy. This distinction reflects the distinction between democracy as a procedural value and as a substantial value. At this point the democratic divide of the EU and the alleged rule of law deficiencies of democratic Polish and Hungarian polities collide to the extent that it makes it awkward for the EU to sustain the by acting punitively towards its symbolically substandard members. However, Ovádek argues that Art. 7 justifies intervention without regard to the scope of EU law. Ovádek argues that EPP gives protection to the Fidesz 
party - which cannot be a source of concern after the split of EPP in 2021. In addition, Ovádek rightly indicates that interventionist publications are widely void of legal theory or methodology (empirically studying 80 publications, none of them turned out to use legal methodology).

Blauberger and van Hüllen (2021) focus on the issue of 'money for democratisation' that resembles the first wave of structural changes in the transition countries scrutinized amply by Sobis and De Vries (2009). Blauberger and van Hüllen (2021) agree with Kelemen (2017) in the twisted argument that the nonelected Commission is more democratic than elected national governments. The authors contemplated the potential outcomes of actually applying conditionality of EU funds. They are not entirely sure whether such a step would play out beneficially for democratization. If open coercion by economic force takes place, the EU evidently loses its posture of being a club of shared values. Furthermore, the authors hint that there might be a cold calculation between costly compliance and premeditated non-compliance beneficial for competitiveness. In such a case, insisting on a coercion policy may appear grotesque when being punished would pay off better than weathering the storm in relations with the EU institutions.

History appears to justify Blauberger and van Hüllen (2021) regarding their statement that the Commission will hardly settle debates with the recalcitrant member states. In fact, the Commission appears to deliver sanctions without bothering with the due process of law by denying access to COVID recovery funds ${ }^{5}$. Such a step can be taken as brinkmanship or harsh negotiation tactics but would be difficult to justify by the principles of the rule of law.

Whether the actual freezing of access to cohesion and structural funds would be beneficial to democratic development or to the prosperity and security of the EU as a continental entity, is highly questionable. It is clear that in such a case funded cohesion and structural development would halt or would take a different route from EU strategies given a prolonged period of sanctions. If agricultural subsidies were also to be held back, this would entail an abrupt change in land prices, food prices and food market in the given country. The given recalcitrant member state might be forced to install protective steps to uphold its agricultural production capacity, internal food supply and agricultural exports. One percent of the GDP of the EU is redistributed by EU institutions while EU funds provide for an important non-indebting source of external financing that had a historical role of boosting development in transition countries. But assuming that this development has been successful, the marginal utility of EU funds is expected to decrease gradually. Sure enough, the occurrence of a long sanctioning period (similarly, to decade-long sanctions against Russia) might ruin the efficacy of billions of ECUs and euros spent before and after the accession of Hungary and Poland while opening independent development perspectives for them. Ceterum censeo, the United Kingdom opted for the independent development path and according to Sti-

5 URL: https://www.politico.eu/article/brussels-turns-down-hungarys-recovery-plan/ (accessed: 08 August 2021). 
glitz (2017), cool, selfish economic calculation may cause the disintegration of certain institutional elements of the EU.

\section{Major flaws in the abrupt change theory - interventionist argument}

\section{Lack of methodology or flawed methodology}

In order to perform proper research, appropriate methodology is required and the same applies to legal studies. Ovádek (2018) recognised this as a general intellectual shortcoming of the interventionist school. Albeit, legal research - according to Levi (1948) - shall be performed with the awareness of social theories and changes in society that are relevant in mitigating ambiguities that might occur during legal reasoning, not without respect to the fact that law itself consists of social artefacts. The main social artefact regarding law is legal grammar itself. "Legal grammar is not really 'neutral', but unavoidably situated within a cultural horizon." (Ballin, p. 5). As such, the ontological paradox of jurisprudence regarding EU law surfaces: Which meaning of highly symbolic terms should be applied when making a judgement on the applicability of Art. 7 of TEU if basic notions that are widely considered equivalent actually differ profoundly? The best example of this is the difference between 'Rechtsstaat' and 'rule of law'. While the former refers to the state that has to maintain and enforce law and justice, the latter emphasizes a more common law-like viewpoint according to which law is inherited and preserved, therefore it has to be fulfilled by public and private entities alike; enforcement relies heavily on the judiciary, while a chartered constitution - and many other elements of written hard law - are not necessarily required. The importance of understanding Rechtsstaat as a concept has long been evident for many authors of public administration theory (Hajnal, 2003; Hajnal, 2008, p. 132; Hajnal, 2014; Hintea-Ringsmuth-Mora, 2006; Drechsler, 2005) with regards to Hungary.

Furthermore, being interventionist first and doing research afterwards creates serious research bias that has not yet been scrutinised sufficiently. Interventionist literature uses shortcuts that consist of semantic bubbles such as "elections were rigged" and "the extreme right is part of the ruling coalition" or the charge of being "anti-semitic". These are hardly scientific affirmations; instead, such remarks indicate the bias of authors who use them in their writings without critique.

Historical analogies with regards to the country-specific interventionist theory

Ágh (2013a, 2013b) refers to the discreditation of Western influence because of poverty and pain caused by liberal reforms, while Pech and Scheppele (2017) on the other hand call for quick and decisive intervention by EU institutions. Interestingly enough, similar proposals were aired regarding Tri-Zone Germany in 1949 "We must face the fact that the contradictions, vacillations, and reactionary manifestations of Western occupation policy have appallingly discredited democracy in Germany, both as a political system and an intellectual outlook" (Gurland, 1949, p. 235). The analogy comes from Payne (2006) who uses the ex-

\footnotetext{
${ }^{6}$ The contrary is true according to Köves, Slomó. URL: https://hungarytoday.hu/hungary-safest-europe-jewsrabbi-koves-first-site-conference/ (accessed: 08 August 2021).
} 
amples of post-war Germany and contemporary Iraq as examples to illustrate that coercive democratisation is doomed to fail. Kinzer (2007) provides an exhausting enumeration of failures of interventions in the $20^{\text {th }}$ century to be used as historical evidence that interventions with the purpose of democratisation tend to backfire.

Lacking the explanation of why the supposed development path of democratisation changed abruptly in Hungary is crucial regarding the applicability of Art. 7. The application of Art. 7 requires a legally relevant purpose, namely, to put back on track the derailed democratisation process of the given country. If, however, measures taken by Art. 7 do not correspond to the causes of the supposed de-democratisation tendency, application of Art. 7 is doomed to fail in content, furthermore, it will have no causal connection with its legally relevant purpose. Sanctions applied without a sound legally relevant purpose of betterment do not fulfil the criteria of the rule of law. (The law developed the notions of general and special prevention to grasp this problem.)

Unlike other authors of the 'abrupt change - interventionist' school, Ágh (2013a; 2013b), Pech and Scheppele (2017) and Kelemen and Blauberger (2017) make at least certain attempts to explain the causes behind the abrupt change of former democratisation. The majority - and the Sargentini report itself - lacks circumstantial inquiry in this regard. This is a decisive shortcoming not only in social science but in legal methodology as well. The Sargentini report - itself a legal document - ought to meet the requirements of proper legal inquiry.

The promoters of the theories of abrupt change do not take into account Francis Fukuyama's explanation of why traditional leftist parties tend to lose ground in industrialised countries (Fukuyama, 2015, pp. 436-440). In his magnum opus, Fukuyama describes how traditional leftist parties had to see the structural decline of their support because of manufacturing industries being relocated to Asia and either diffused into a larger middle class or descended into a diverse lower class. As the lower classes in services became more diverse, leftist parties turned to identity politics and turned away from social mobilisation by class and labour issues.

The lack of explanations on why the development path changed abruptly becomes more peculiar as theorists do not tend to think that bad policies delivered by leftist parties between 2002 and 2010, or furthermore the foundations of the regime change decisively influenced by policy transfer mechanisms and technical assistance of the 1990s (Sobis and De Vries, 2009), might have had a causal relationship with certain elements of the development path that were used as circumstantial evidence against Hungary under Art. 7.

\section{'Backsliding' assumes a prior, higher position in democracy that actually never existed}

The theory of backsliding (in legal terms: serious breach of the rule of law ought to be in a causal relationship with the potential or actual detriment of Art. 2 values) - can be conceived only if there had been a higher level of democracy that is now deteriorating. Still, authors do not offer a point of reference from where the backsliding could have possibly started or how it could be measured. In fact, universal backsliding could not be substantially underpinned if one took into account the police brutalities of the Socialist-liberal 
government in 2006 covered up by the judiciary (or threatening church schools of withdrawing their finances, mass layoffs in public administration on political basis, outright corruption cases and excessive foreign currency loans, curtailing the competencies of the Constitutional Court by so called 'harakiri-norms', etc..). Bad policies ${ }^{8}$ brought tremendous pain, poverty and suffering to the public (such as the decrease of per capita GDP) that are generally considered perils for democracy (Share, 1984; Huntington, 1985; Ágh, 2013a).

\section{The lack of understanding of the development path of the regime change}

The lack of contextual analysis is obvious when neither authors of political science (post-communist studies) nor of legal studies engage in the lasting consequences of the lack of lustration in Hungary (Coman, 2014). This is a major shortcoming of comprehending the current context of Hungarian democracy. Authors do not discuss the fall of Socialist prime minister Péter Medgyessy in 2004 after it turned out that he had served communist counterintelligence services under codename D-209. One cannot overestimate the power of those unknown individuals who are in possession of such secret agent files. If the prime minister (in charge of contemporary secret services and an experienced secret agent himself) could not protect himself from such an attack, how would an ordinary judge be able not to distort his rulings in favour of a blackmailer? We do not know. What we know though is that there was no lustration in the judiciary. This was discerned by the World Bank but not by interventionist authors. Anderson, Bernstein and Gray (2005) wrote the following: "The transition from socialism to capitalism in Central and Eastern Europe and the Baltics (CEE) and the Commonwealth of Independent States (CIS) has required a fundamental reorientation of legal and judicial institutions. During socialist times they were subordinate to the executive and the Communist Party, and their role in the commercial sphere was oriented almost entirely toward enforcing the governments' economic plans." (Anderson et al., 2005, p. xi). In fact, leadership positions in the judiciary used to require political engagement from the Hungarian Socialist Workers' Party. This is a non-issue for academic authors but was a reality when the Hungarian Parliament decided to lower the age of retirement of the affected generation. The lack of lustration in the judiciary resembles the situation described by Payne (2006) regarding de-nazification of postwar Germany (Gurland, 1949). It was a major dilemma for the theorists of the day as to what extent to let former Nazis participate in the judiciary or public life. The dilemma is real: is it a workable democracy that depends on those who were compromised in a prior dictatorship and actively fought against democrats?

\footnotetext{
7 So called "harakiri-norms" consist of legal material modifying another law but with the clause that the modifying norm automatically loses effect after the modification takes place. The Constitutional Court during its procedures cannot create new norms, its competences are limited to 'negative legislation'. As such, cessation of a given norm that had been modified by a harakiri-norm prevents the Constitutional Court of re-installing the legal text prior to the modification. This limits the de facto range of action of the Constitutional Court that has to judge whether the norm in force - however problematic - or no norm at all would be less harmful but does not have the capability of settling the matter by upholding the regulation before the modification in question.

8 URL: https://worldview.stratfor.com/article/hungary-just-first-fall (accessed 08 August 2021).
} 
In Hungary this has never been settled and it appears that rule of law institutions developed in the 1980s and 1990s defended the incumbents. Corrections to this appear as a breach of the rule of law to many contemporary academic authors.

\section{The issue of moral authority}

Hellquist (2019) rightly captures the importance of the symbolic-moral posture of sanctioning and being sanctioned. Still, authors do not state that member states promoting sanctions against Poland and Hungary would be flawless. Regarding certain human right challenges in Western Europe, a quick list on news media reports might put the symbolic-moral battle into a different perspective. It appears that it is only a matter of research to find developments in pro-sanction countries which potentially undermine their moral high ground as a universal precondition to sanctions applied either internally or externally, however this has not caught the attention of interventionist theorists yet.

\section{Conclusions}

The main theoretical question discussed in this paper at length is whether any country could or should be democratised by various forms of transaction or, furthermore, coercion. The examples of post-WWII. Japan and Germany are generally taken as successful examples. Payne (2006), however, stated that these examples are in fact examples of the opposite: actual democratisation in these cases took place not because of but in spite of external influence. Historical examples always have to be handled with care because of the profoundly different contexts. According to Cristopher Pollitt, "knowledge of what works and what does not tends to be heavily context dependent" (Pollitt, 2003, p. 122).

In order to revisit the Hungarian context of democratisation, the main conclusions of Rustow (1970), Huntington (1984) and Share (1987) have been used on transactional democratisation to draw a line of thought between the generation of cold war authors and contemporary interventionist thinkers such as Ignatieff (2005), Pech and Scheppele (2017a, b), Kelemen and Blauberger (2016), Kazai (2021), Appel (2019), Kochenov (2016), Coman (2014), etc., who tend to focus on the applicability of Art. 7 as a means to correct the development paths of Hungary and Poland even by a certain level of coercion. Art. 7 as such is a means for (re-) democratisation by transaction.

Instead of an off-the-shelf approach, I propose the following logical steps to judge democratisation by transaction:

1. I propose that the "Payne-theorem" should be used as a blueprint for deciding whether a country is democratic i.e. "moderation of the amount of leadership political violence".

The Payne-theorem has definite advantages: it embraces historical evidence while it does not need lengthy explanations. The Payne-theorem is appropriate to be used as a universal principle in the following formulation:

If there is moderation of leadership political violence, the given country cannot be considered as a legitimate target of democratic intervention. 
I refrain from trying to justify various sorts of coercion (potentially) including violence by a reverse Payne-theorem as it would be far beyond the scope of this article. Similarly, the Payne-theorem should not be considered as a universal norm: it refers solely to democratisation.

2. No good ends stem from using bad means: democratic transactions should not be violent. Violent transactions shall be rendered per se undemocratic and therefore ontologically contrary to democratisation.

3. Rule of law and democratisation ought to go together: transactional democratisation should be based on the rule of law. The law of the given country and/or international law.

It is to be emphasized that there is a robust organic-contextual school of democracy that is practically not considered by interventionists. This - otherwise rich and diverse - realm of thought is coined by such names as Ratzinger (2007), Habermas and Ratzinger (2007), Habermas (1996), Shiva (2015), Pollitt (2013), Morçöl (2014), Hazony (2018) and Payne (2006), no less. I propose that academic inquiry as well as actual political actors should revisit these thoughts in order to narrow the gulf between institutional ambitions and historical realities.

\section{REFERENCES}

Ágh, A. et al. (1984) Szocialista orientáció [Socialist orientation]. Budapest: Kossuth Publisher.

Ágh, A. (1975a) A marxi történetfilozófia alakulása [The development of Marxian philosophy on history]. Budapest: Akadémiai Publisher.

Ágh, A. (1975b) Bevezetés a marxizmus-leninizmus társadalom és történetelméletébe [Introduction to the societal and historical theory of Marxism-Leninism] Budapest: Oktatási Minisztérium Marxizmus-Leninizmus Oktatási Főosztálya [Department for The Education of Marxism-Leninism, Ministry of Education].

Ágh, A. (2013a) 'Bumpy road of the Hungarian administrative reforms: From political over-centralization to public policy failures', Politika i Uprava. Croatian and Comparative Public Administration, 13(4), pp. 1115-1136.

Ágh, A. (2013b) 'The triple crisis in Hungary: The "Backsliding” of Hungarian Democracy after Twenty Years', Romanian Journal of Political Science (PolSci), 13(1), pp. 25-51.

Almond, G. and Verba, S. (1963) The Civic Culture. Princeton

Anderson, J.H., Bernstein, D.S. and Gray, Ch.W. (2005) Judicial Systems in Transitional Economies. Assessing the Past, Looking to the Future. The World Bank, Washington DC. Available at: https://openknowledge.worldbank.org/bitstream/handle/10986/7351/329 280Judicial0Sys01public1.pdf? sequence $=1$ \&isAllowed $=y$ (downloaded 08 August 2021).

Appel, H. (2019) 'Can the EU stop Eastern Europe's illiberal turn?' Critical Review, 31, (3-4), pp. 255-266. 
Ballin, E.H. (2020) Advanced introduction to legal research methods. Cheltenham, UK: Edward Elgar Publishing.

Barker, E. (1942) Reflections on Government, Oxford, p. 63.

Borvendég, Z. (2020a) Az impexek kora [The age of impexes]. Budapest: Kárpátia Stúdió Publisher.

Borvendég, Z. (2020b) Mesés kémjátszmák. A nyugati külkereskedelmi hálózatok kiépülése 1945 után. [Fabulous spy games. Building up western foreign trade networks after 1945.] Budapest: Magyarságkutató Intézet. Available at: http://mek.oszk.hu/21300/21398/21398. pdf (downloaded 01 August 2021).

Civil Jogász Bizottság jelentése a 2006 szeptember-októberi emberi jogsértésekről. [Report of the Civic Lawyer Commission on the breaches of human rights September-October, 2006]. Kairosz Publisher, 2007.

Closa, C. (2019) 'The politics of guarding the Treaties: Commission scrutiny of rule of law compliance', Journal of European Public Policy, 26 (5), pp. 696-716.

Coman, R. (2014) 'Quo vadis judicial reforms? The quest for judicial independence in Central and Eastern Europe', Europe-Asia Studies, 66 (6), pp. 892-924, DOI: 10.1080/ 09668136.2014.905385 (but not in the context of Hungary).

Connaughton, B., Sootla, G., Peters, G. (eds.) (2008) Politico-administrative relations at the centre: Actors, structures and processes supporting the core executive. Bratislava: NISPAcee.

Cutright, Ph. (1963) 'National political development: Measurement and analysis', American Sociological Review, XXVIII (April).

Diamond, L., Linz, J.J. and Lipset, S.M. (1989) Democracy in developing countries. Vol. 4, Latin America. Boulder, Co.: Lynne Rienner and London: Adamantine Press.

Drechsler, W. (2005) 'The rise and demise of the new public management', Post-Autistic Economics Review, 33, 14 September.

European Commission for Democracy through Law (Venice Commission) Report on the Rule of Law Report by the Venice Commission Adopted at the $86^{\text {th }}$ Plenary Session, Venice, 25-26 March, 2011. Available at: https://www.venice.coe.int/webforms/documents/ default.aspx?pdffile=CDL-AD(2011)003rev-e (downloaded 06 August 2021).

Fukuyama, F. (2012) 'The weakness of liberal populism, in Garfinkle, A. (ed.) Plutocracy \& democracy. How money corrupts our politics and culture. Washington DC: The American Interest EBOOK.

Fukuyama, F. (2015) Political order and political decay. From the industrial revolution to the globalization of democracy. New York: Farrar, Strauss and Giroux.

Gurland, R.L. (1949) 'Why democracy is losing in Germany', Commentary 8 (September), pp. 227-37.

Habermas, J. and Ratzinger, J. (2007) Dialectics of secularisation: On reason and religion. San Francisco: Ignatius Press.

Habermas, J. (1996) Between facts and norms: Contributions to a discourse theory of law and democracy. Cambridge: Polity Press. 
Hajnal, G. (2003) 'Diversity and convergence: a quantitative analysis of European public administration educational programs', Journal of Public Affairs Education, 9(4), pp. 245-258.

Hajnal, G. (2008) 'Public management reforms: Hungary', in Public Management Reforms in Central and Eastern Europe. Edited: Bouckaert, G., Nemec, J., et. al. Bratislava, Slovakia: NISPAcee Press, pp. 121-150.

Hajnal, G. (2014) 'Public administration education in Europe: Continuity or reorientation?' Teaching Public Administration. Published online: 11 June 2021.

Hazony, Y. (2018) The virtue of nationalism. New York: Basic Books.

Hellquist, E. (2019) 'Ostracism and the EU's contradictory approach to sanctions at home and abroad', Contemporary Politics, 25(4), pp. 393-418.

Hintea, C., Ringsmuth, D. and Mora, C. (2006) 'The reform of the higher education public administration programs in the context of public administration reform in Romania', Transylvanian Review of Administrative Sciences, 16(E), pp. 40-46.

Huntington, S.P. (1984) 'Will more countries become democratic?' Political Science Quarterly, 99(2) (Summer), pp. 193-218.

Ignatieff, M. (2005) 'Who are Americans to think that freedom is theirs to spread? New York Times Magazine, June 26, 42-47.

Kazai, V.Z. (2021) 'The misuse of the legislative process as part of the illiberal toolkit. The case of Hungary', The Theory and Practice of Legislation. Available at: https://doi.org/ $10.1080 / 20508840.2021 .1942366$

Kelemen, D.R. (2017) 'Europe's other democratic deficit: National authoritarianism in Europe's democratic union', Government and Opposition, 52(2), pp. 211-238.

Kelemen, D.R. and Blauberger (2016) 'Introducing the debate: European Union safeguards against member states' democratic Michael backsliding', Journal of European Public Policy, 24 (3), pp. 317-320.

Kinzer, S. (2007) Overthrow. America's century of regime change from Hawaii to Iraq Times Books.

Kochenov, D.V. (2016) 'The commission vs Poland: The sovereign state is winning 1-0', VerfBlog, 2016 January 25.

Kochenov, D.V. (2008) EU enlargement and the failure of conditionality. Pre-accession Conditionality in the fields of democracy and the rule of law. Kluwer Law International.

Kornai, J. (1996) 'Paying the bill for goulash communism: Hungarian development and macro stabilization in a political- economy perspective', Social Research, 63 (4), pp. 943-1040.

Lerner, D. (1958) The passing of traditional society: Modernizing the Middle East. The Free Press, Glencoe.

Levi, E.H. (1948) 'An introduction to legal reasoning', University of Chicago Law Review, 15 (3), pp. 573-574. 
Lipset, S.M. (1959) 'Some social requisites of democracy: Economic development and political legitimacy', American Political Science Review, LIII (March);

Morçöl, G. (2014) A complexity theory for public policy. UK: Routledge.

Orenstein, M.A., Bloom, S. and Lindstrom, N. (2008) 'A fourth dimension of transition', in Orenstein, M.A., Bloom, S. and Lindstrom N. (eds) Transnational actors in Central and East European Transitions. Pittsburgh, PA: University of Pittsburgh Press, p. 2.

Ovádek, M. (2018) 'The rule of law in the EU: Many ways forward but only one way to stand still?', Journal of European Integration, 40 (4), pp. 495-503.

Payne, J.L. (2006) 'Did the Unites States create democracy in Germany?', The Independent Review, XI (2), pp. 209-221.

Pech, L. and Scheppele, K.L. (2017a) 'Poland and the European Commission', Par I: A dialogue of the deaf, VerfBlog, 3 January 2021.

Pech, L. and Scheppele, K.L. (2017b) 'Illiberalism within: Rule of law backsliding in the EU', Cambridge Yearbook of European Legal Studies, 19, pp. 3-47.

Pollitt, C. (2003) 'Public management reform: Reliable knowledge and international experience’, OECD Journal on Budgeting, 3 (3), pp. 121-136.

Ratzinger, J. (2007) Europe today and tomorrow. Addressing the fundamental issues. Kindle edition. San Francisco: Ignatius Press.

Rech, W. (2018) 'Some remarks on the EU's action on the erosion of the rule of law in Poland and Hungary', Journal of Contemporary European Studies, 26 (3), pp. 334-345.

Ropret, M., Aristovnik, A. and Kovac, P. (2018) 'A content analysis of the rule of law within public governance models: Old vs. new EU member states', NISPAcee Journal of Public Administration and Policy, 11(2), pp. 129-152.

Rustow, A.D. (1970) 'Transitions to democracy: Toward a dynamic model', Comparative Politics, 2 (3), Apr., pp. 337-363.

Share, D. (1987) 'Transitions to democracy and transition through transaction', Comparative Political Studies, 19 (4), January, pp. 525-548.

Shiva, V (2005, 2015) Earth democracy. Justice, sustainability and peace. Berkeley, California: North Atlantic Books.

Sobis I. and de Vries, M.S. (2009) The story behind the Western advice to Central Europe during its transition period. Bratislava, Slovak Rep: NISPA CEE Press.

Soyaltin-Colella, D. (2020) 'The EU's 'actions-without-sanctions?' The politics of the rule of law crisis in many Europes', European Politics and Societies, 22 (3), pp. 1-17. Available at: https://doi.org/10.1080/23745118.2020.1842698

Stiglitz, J.E. (2017) The Euro. How a common currency threatens the future of Europe. Updated edition. New York: W. W. Norton \& Co.

The article was submitted: 06.09.2021; approved after reviewing: 20.09.2021; accepted for publication: 28.11.2021. 